\title{
FRANČIŠKANSKE KORNE KNJIGE V NOVEM MESTU IZ 18. STOLETJA*
}

\author{
RADOVAN ŠKRJANC \\ Muzikološki inštitut ZRC SAZU
}

Izvleček: Prispevek predstavlja nekatera osnovna dejstva o glasbeni in liturgični vsebini ter izvoru osmih kornih knjig iz 18. stoletja v Knjižnici Frančiškanskega samostana v Novem mestu. Knjige so rokopisi z značilnim repertoarjem frančiškanskih glasbenikov tistega obdobja, namenjenim za bogoslužno rabo. Njegova podrobnejša analiza in primerjava s sočasno frančiškansko glasbo $v$ drugih deželah srednje Evrope še nista bili opravljeni; tudi pomen, ki ga je imel ta repertoar za razvoj cerkvene glasbe na Slovenskem $v 18$. stoletju, še ni bil ovrednoten.

Ključne besede: cerkvena glasba, frančiškani, glasba 18. stoletja

\begin{abstract}
The paper presents some basic information about the musical and liturgical contents as well as the origin of eight eighteenth-century choir books preserved in the library of the Franciscan monastery in Novo mesto. They are manuscripts of a rather specific music repertory used by Franciscans at their religious services. A more detailed analysis of this repertory and its comparison with contemporary Franciscan music from other parts of central Europe should still be done in the future. The same is true for examining this repertory from the viewpoint of its influence on the growth of church music in Slovenia in the eighteenth century.
\end{abstract}

Keywords: church music, Franciscans, eighteenth-century music

Glasba v samostanih frančiškanske (hrvaško-kranjske) province sv. Križa je v 18. stoletju doživela izjemen razcvet. Razmere zanj so bile v tem obdobju posebno ugodne in spodbudne. Spoznanje o nujnosti približevanja načina verskega delovanja »vsem slojem v narodu« je bilo na Slovenskem, kot ugotavlja Metod Benedik, živo že vse od časa škofa Tavčarja naprej, ki se je pri svojem prizadevanju za prenovo cerkve dobro zavedal, da »je nosilec vernosti v prvi vrsti celoten narod, ne le kakšen sloj ali stan. $\aleph^{1}$ Vendar pa je v glasbi to spoznanje v celoti zaživelo šele dobrih sto let pozneje, ob koncu 17. in še bolj v začetku 18. stoletja, ko so se tudi pri nas - tako kot v vsej srednji Evropi - uveljavile

* Prispevek je avtorjev referat na znanstvenem simpoziju ob 500-letnici Slovenske frančiškanske province sv. Križa Sobratom svojim v dediščino milo (Ljubljana, Frančiškanski samostan Ljubljana, 12. in 13. september 2014).

1 Benedik, »Protireformacija in katoliška prenova«, 126. 
razne nove oblike glasbe v cerkvah, »uglašene« z duhovnimi potrebami preprostejših ljudi. Ti pa so bili frančiškanom kot ubožnim redovnikom že od nekdaj posebno blizu.

Poleg maš tipa »missa ruralis« - to je bila značilna oblika cerkvenih skladb za rabo v manj zmogljivem okolju na podeželju in v manjših mestih, ki so jo od približno tridesetih let 18. stoletja naprej gojili zlasti južnonemški mojstri - je bila t. i. frančiškanska maša (»missa franciscanorum« oz. »missa francescana«) tista, ki je glasbo v bogoslužju najbolj približala okusu navadnih ljudi, in sicer že ob koncu 17. stoletja, še bolj pa v začetku naslednjega. Zato je možno, kot ugotavlja Wilfried Dotzauer, da so ravno frančiškani s svojo glasbo najpomembneje vplivali na nastanek in razvoj omenjene podeželske cerkvene glasbene prakse, ki se je v srednji Evropi v večji meri razmahnila okoli sredine 18. stoletja. ${ }^{2}$

Oba têrmina - podeželska in frančiškanska maša - je seveda treba razumeti širše, tj. kot nekakšni skupni imeni za različne uglasbitve cerkvenih besedil, ki izražata vse bistvene značilnosti ene in druge glasbene prakse oziroma dveh razmeroma specifičnih in razpoznavnih slogov v cerkveni glasbi 18. stoletja. Praksi sta bili vsebinsko resda v marsičem podobni, vendar tudi različni; na zunaj že po tem, da so skladbe t. i. bavarskih mojstrov - prav tako redovnikov, vendar večinoma benediktincev, kot sta bila p. Valentin Rathgeber (1682-1750) in p. Marianus Königsperger (1708-1769), ter tudi župnijskih in laičnih samostanskih organistov, npr. Johanna Antona Kobricha (1714-1791) in pozneje Johanna Melchiorja Dreyerja (1747-1824) - krožile po območju srednje Evrope večinoma v obliki tiskov, izdanih pri Lotterju ali kateri drugi augsburški založbi, medtem ko se je repertoar frančiškanskih redovnikov širil skoraj izključno s prepisi, torej v obliki rokopisov, in le znotraj samostanov tega reda. Pri vsaki od obeh navedenih praks je kljub očitnemu medsebojnemu vplivanju razbrati razmeroma avtonomno razvijanje lastnih kompozicijskih in izvajalskih glasbenih prvin.

Kljub večji zapostavljenosti frančiškanske in tudi južnonemške cerkvene glasbe 18 . stoletja v sodobnem zgodovinopisju - morda prav zaradi njunega poudarjenega »ljudskega« značaja, ki obe glasbi pomembno razlikuje od t. i. »slovesne« cerkvene glasbe v večjih katedralah kot domnevne nosilke razvoja ustvarjanja na tem področju - so vsaj temeljne značilnosti repertoarja frančiškanskih glasbenikov 17. in 18. stoletja v srednji Evropi že nekaj časa znane. Gre za slogovno sklenjen in razmeroma obsežen repertoar različnih vokalno-instrumentalnih in tudi samo instrumentalnih skladb za bogoslužno rabo, navadno zbranih v t. i. kornih knjigah za organiste (nem. »Schlagbücher«; glagol »schlagen« je v tistem času navadno zamenjaval glagol »spielen«, ko je pomenil igranje na instrumente s tipkami). Nekaj takšnih knjig s področja Avstrije je namreč že v šestdesetih letih prejšnjega stoletja podrobneje preučila Friederike Grasemann. V svoji študiji frančiškanske glasbe od konca 17. do konca 18. stoletja je analitično razčlenila njene kompozicijske značilnosti in verjetne načine izvajanja skladb, ki so v teh knjigah, in sicer z vidika razvoja obojega v treh slogovnih obdobjih: prvem ob izteku 17. stoletja, drugem v prvi polovici 18. stoletja in tretjem po sredini 18 . stoletja. ${ }^{3}$

$\mathrm{S}$ to študijo začeto raziskovanje frančiškanske glasbene kulture v obeh stoletjih je nato nadaljeval slovaški muzikolog Ladislav Kačic, ki je ob koncu prejšnjega stoletja

2 Prim. Dotzauer, Die kirchenmusikalischen Werke Johann Valentin Rathgebers, 102-108.

3 Prim. Grasemann, »Die Franziskanermesse des 17. und 18. Jahrhunderts«, 72-124. 
preučeval frančiškanske maše s preloma 17. in celotnega 18. stoletja v nekdanji madžarski provinci sv. Marije. ${ }^{4}$ Šele tretji obsežnejši prispevek na tem področju, ki pa ne obravnava frančiškanske glasbe s sedanjega slovenskega in hrvaškega ozemlja, je leta 2007 objavljeni tematski katalog skladb frančiškanskega reda iz 17. stoletja v madžarskem Podkarpatju. ${ }^{5}$

Za preučevanje pretekle frančiškanske glasbe pri nas so posebno dragocene objave izsledkov raziskav glasbenih arhivov v frančiškanskih samostanih na Hrvaškem, ki jih od konca sedemdesetih let preteklega stoletja dalje opravljajo tamkajšnji muzikologi in jih deloma povzema Kinderićeva knjiga Franjevci uz orgulje iz leta 2006. ${ }^{6}$ Tako kot v drugih objavah hrvaških kolegov najdemo tudi v tej številne podatke, ki se neposredno dotikajo glasbene dediščine frančiškanov na slovenskih tleh, zlasti tiste iz časa delovanja skupne slovenske in hrvaške province sv. Križa (1708-1900). ${ }^{7}$

Še mlajšega datuma je prva podrobnejša študija ene od frančiškanskih kornih knjig 18. stoletja, nastalih v slovenskem delu te province. Gre za študijo šele pred kratkim odkritega Cantula iz Brežic, ki jo je opravil Matjaž Barbo in v kateri avtor med drugim ugotavlja precejšnje ujemanje vsebine brežiške pesmarice z značilnostmi frančiškanskega glasbenega opusa (»opus franciscanorum «) ${ }^{8}$ na Slovaškem, kljub večji geografski oddaljenosti slovenskih in slovaških samostanov. ${ }^{9}$ To po eni strani krepi domnevo o močnem prepletanju glasbenega repertoarja ne le znotraj te ali one redovne province (tako prepletanje razkrivajo pri brežiški pesmarici številne vzporednice z vsebino kornih knjig v Novem mestu), temveč tudi preko njihovih meja. ${ }^{10}$

4 Kačic, »Missa franciscana der Marianischen Provinz im 17. und 18. Jahrhundert«, 5-107. Kačic je avtor še več drugih razprav o frančiškanski glasbi 17. in 18. stoletja. Prim. Kačic, »'Opus franciscanum' v zápise a zvukovnej podobe«; isti, »Mehrstimmiger Gesang der Franziskaner in Mitteleuropa im 17. Jahrhundert«; isti, »Figuralmusik der Franziskaner in Mitteleuropa«.

5 Richter, Der Melodienbestand des Franziskanerordens im Karpatenbecken im 17. Jh.

6 Kinderić, Franjevaci uz orgulje. Prim. tudi Riman, »Barokna glazba u franjevačkom samostanu na Trasatu u Rijeci«, 19-34; Popis muzikalija u Knjižnici franjevačkog samostana u Samoboru.

7 Leta 1514 se je nekdanja bosanska vikarija, ki velja za pramater današnji frančiškanski provinci sv. Križa, zaradi turških osvojitev na njenem ozemlju razdelila na dve provinci: na provinco Bosno Srebreno (»Bosnae Argentinae«), ki je obsegala samostane pod turško oblastjo, in provinco Bosno Hrvaško (»Bosnae Croatiae «) s samostani na svobodnem delu vikarije (tj. v osrednjih delih hrvaškega kraljestva med Vrbasom in Kolpo ter med Savo in Jadranom). Že prej (leta 1469) so iz nje v Novo mesto pribežali manjši bratje, pozneje (leta 1565) pa še na Sveto Goro pri Gorici. Observantska provinca Bosna Hrvaška je v prvih petdesetih letih izgubila veliko večino samostanov, ki so bili leta 1514 v njenem okviru, ostala sta le samostana na Trsatu in v Senju. Izgube zaradi turške osvojitve novih ozemelj so skušali nadosmestiti z ustanavljanjem novih samostanov. Tako je imela provinca ob koncu 17. stoletja 15 samostanov in dva hospica na sedanjem slovenskem in hrvaškem ozemlju. Leta 1708 si je zato privzela ustreznejše ime Hrvaško-kranjska provinca sv. Križa. V času ilirskih provinc je izgubila nekaj samostanov, po odhodu Francozov pa se je v skoraj nespremenjenem obsegu in s starim imenom obdržala vse do leta 1900, ko je bila z dekretom razdeljena na dve narodni provinci: hrvaško sv. Cirila in Metoda, ter kranjsko sv. Križa. Takrat sta se kranjski provinci pridružila tudi samostana pri Sv. Trojici v Slovenskih Goricah in v Mariboru. Prim. Škofljanec, »Red manjših bratov (O.F.M.) in provinca sv. Križa«, 10-79.

8 Prim. Kačic, »'Opus franciscanum' v zápise a zvukovnej podobe«, 136-45.

9 Barbo, »'Cantual' brežiškega frančiškanskega samostana«, 257-273.

${ }^{10}$ Nav. delo, 258-260. 
Po drugi strani pa je potrebno pregledati, in sicer z vidika omenjenih povezav, še preostale korne knjige naših samostanov. Ob dejstvu, da imajo skupne ali vsaj podobne značilnosti kot franšiškanski opusi 18. stol. v drugih deželah srednje Evrope, ki so že bili raziskani, se razkrivajo namreč nekakšne »čez-provincialne« posebnosti frančiškanske glasbe tega časa in območja. ${ }^{11}$

Gre za osem razmeroma lepo ohranjenih rokopisnih knjig, ki jih hrani Knjižnica novomeškega frančiškanskega samostana. ${ }^{12}$ Vsem so skupne vsaj glavne tri od omenjenih značilnosti frančiškanske glasbe z nekaj odstopanji.

Prva med njimi je skoraj popolna anonimnost vsebovanih skladb. Izjema je le omemba frančiškanskega redovnika p. Petra Chrysologa Pachmayra v Ms. mus. 245, ki je na zadnji strani edine uglasbitve besedila Stabat Mater v tem rokopisu (gl. sliko 1), vendar kot navedek avtorstva skladbe velja morda za uglasbitev sledečih Marijinih litanij, posvečenih Pachmayrovemu patronu (S. Petri Chrysologi Ep. \& Eccles. Doctoris). V Leksikonu bavarske glasbe Josepha Felixa Lipowskega, natisnjenem v Münchnu leta 1811, izvemo, da je bil Pachmayr rojen v bavarskem Dietfurtu leta 1742 in kot dvajsetleten sprejet med frančiškane; bil je izjemen organist in avtor številnih tedaj zelo priljubljenih cerkvenih del. ${ }^{13}$

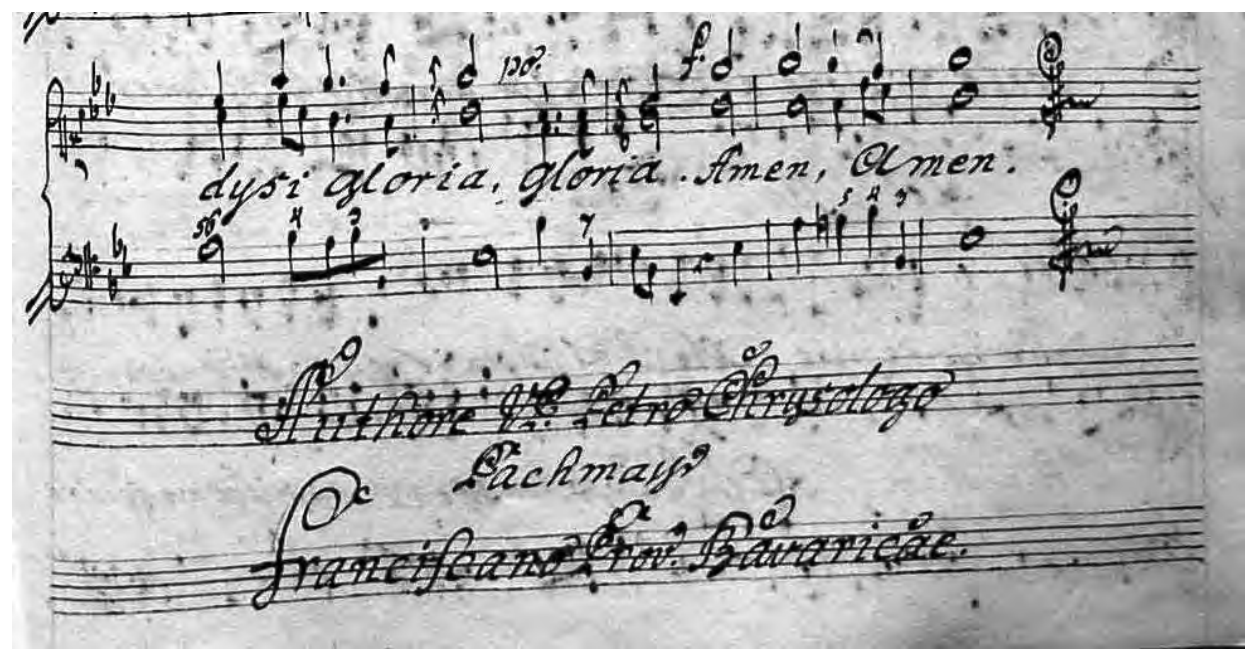

\section{Slika 1}

Zapis imena p. Petra Chrysologa Pachmayra kot avtorja skladbe v rokopisu SI-Nf, Ms. mus. 245, del strani 185 (Frančiškanski samostan Novo mesto, z dovoljenjem)

Verjetno bo avtorstvo še katere od zdaj anonimnih skladb v teh novomeških knjigah sčasoma postalo znano. Tu lahko pomaga zlasti primerjava njihove vsebine s popisom rokopisov skladb, ki ga vodi Mednarodno muzikološko društvo v okviru projekta RISM.

${ }^{11}$ Te posebnosti je sistematično razdelal in povzel v šestih točkah L. Kačic. Prim. Kačic, »Missa franciscana der Marianischen Provinz im 17. und 18. Jahrhundert«, 5-6.

12 SI-Nf, Ms. mus. 90-94, 245-247.

${ }^{13}$ Prim. Lipowsky, Baierisches Künsler-Lexikon, zv. 2, 34. 
Drugi dve značilnosti skladb v novomeških kornih knjigah sta t. i. »klavirski zapis« glasbe $\mathrm{z}$ besedilom med notnima črtovjema, $\mathrm{tj}$. zapisovanje skladb v particellu (glej sliko 1$),{ }^{14}$ in njihova zasedba, ki jo takšen zapis vsebuje in obsega le enega ali dva vokalna glasova »v desni roki« ter orgle, zapisane na način continua »v levi roki«.

Solistični pevski odseki (»Solo«) so večinoma za enega ali dva sopranista, ki sta ponekod res označena s »Canto I« in »Canto II«, medtem ko so zborovski odseki, označeni kot »Tutti«, najpogosteje enoglasni in prav tako sopranski.

Ne glede na to pa je precej verjetno, da je poleg sopranistov pri petju sodeloval vsaj še organist, in sicer kot basist (tako je na podlagi takih odlomkov v avstrijskih kornih knjigah, kjer je pod pavzami »v desni roki« in nad generalnim basom »v levi roki« izpisano besedilo, sklepala že Friederike Grasemann). Na to, da je imel organist tudi pevsko vlogo, kažejo morda tudi sicer redkejši primeri skladb, kakršna je uglasbitve himne $A h$ ! Cor quid hic deperis v novomeškem Ms. mus. 92, ki je v obliki recitativa in krajše arije da capo za basista in continuo.

Bolj gotovo je, da so takšno reducirano zasedbo skladb z enim ali dvema pevskima glasovoma in orglami, kot jo nakazujejo zapisi frančiškanske glasbe v particellu, pri izvajanju bogatili še drugi instrumenti, zlasti v drugi polovici 18. stoletja, in sicer največkrat s colla parte spremljavo dveh godal in improvizacijo pihal ad libitum.

To seveda ponovno odpira vprašanji o dejanski zasedenosti pevskega sestava pri izvajanju frančiškanskih skladb (zapisanih v particellu) in izvirni vlogi frančiškanskih kornih knjig v tedanji izvajalski praksi. Ob tem velja spomniti na značilno zasedbo pevskih in instrumentalnih glasov v omenjeni podeželski cerkveni glasbi južnonemških skladateljev. Posamezni glasovi so tu sicer zapisani ločeno, v t. i. glasovnih zvezkih ali separatih, vendar pa podobno kot ohranjeni frančiškanski particelli obsegajo navadno le dva ali tri obvezne glasove (sopran oz. sopran in bas ter orgle) in šest glasov ad libitum (alt in tenor, dve violini colla parte in dve trobili). Pomembno je tudi to, da arhivi $\mathrm{s}$ frančiškansko glasbo v Sloveniji ne hranijo prepisov vokalnih partov skladb, ki so v frančiškanskih kornih knjigah, kar pomeni, da so te najverjetneje služile organistu - tako kot brežiški Cantual - in ne pevcem, še zlasti pa »ne petju zbora, saj je tudi zapis za tako rabo daleč premajhen in nečitljiv, « kot za brežiško pesmarico ugotavlja Barbo. Vsaj »sodelovanje zbora je zatorej moralo sloneti na memoriranju posameznih njemu namenjenih pevskih odsekov,« izvajanje glasbe na pamet, brez not torej, pa je bilo morda povezano z improviziranjem tistih vokalih glasov, ki jih frančiškanski particelli iz Novega mesta ne vsebujejo. Hkrati pa v njih srečamo zapise, ki v sopranskem ključu notirane melodije namenjajo tenorju in altu (gl. sliko 2), ter še nekatera druga, sicer redkejša odstopanja od opisanega načina zapisovanja frančiškanskih skladb.

Posebno opazna so ta odstopanja v Ms. mus. 245, ki na več mestih vsebuje odlomke, notirane $\mathrm{v}$ treh vrstah, največkrat zaradi izpisanih partov obligatnih orgel in pevskega basa (gl. sliko 3); v tej knjigi je tudi triglasna a cappella uglasbitev besedila Crucifixus.

Ta knjiga je med novomeškimi kornimi knjigami edina, ki neposredno predpisuje uporabo godal. Gre za razmeroma pogoste zaznamke, kot sta »Violino da capo《 ali samo »violino«. Takšni zaznamki so ob krajših in tudi nekoliko daljših solističnih instrumentalnih

${ }^{14}$ Prim. Kačic, »Missa franciscana der Marianischen Provinz im 17. und 18. Jahrhundert«, 5. 


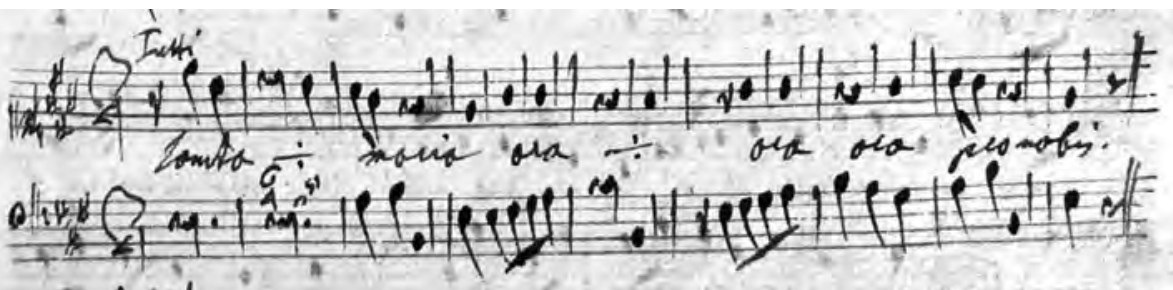

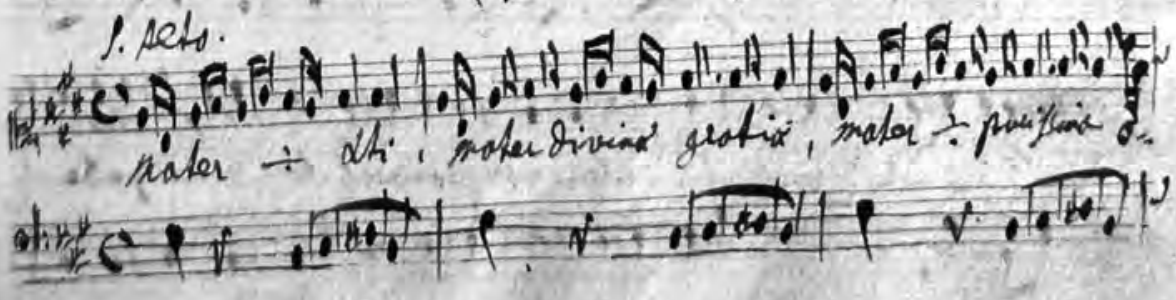

\section{Slika 2}

Oznaka »S[olo] Alto« nad melodijo, zapisano v sopranskem ključu v rokopisu SI-Nf, Ms. mus. 245, del strani 31 (Frančiškanski samostan Novo mesto, z dovoljenjem)

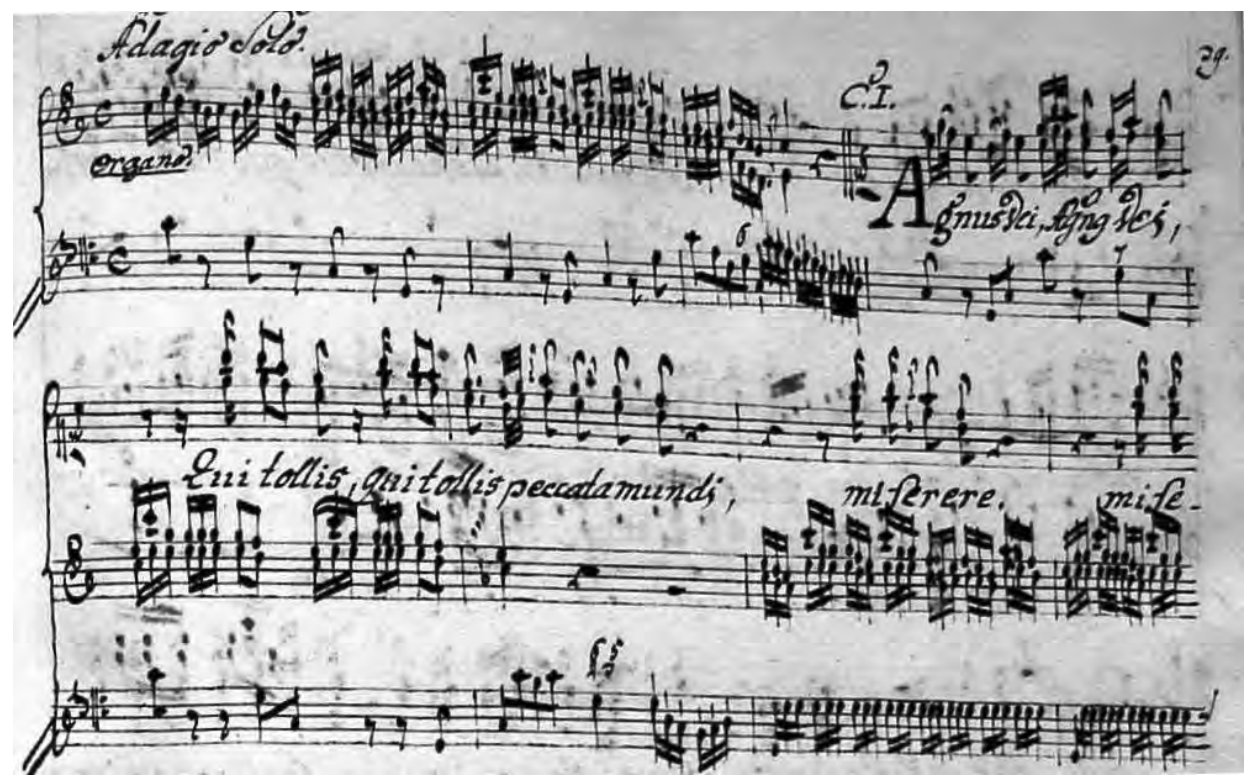

\section{Slika 3}

Zapis glasu obligatnih orgel in soprana $\mathrm{v}$ treh notnih črtovjih v rokopisu SI-Nf, Ms. mus. 245, del strani 39 (Frančiškanski samostan Novo mesto, z dovoljenjem) 
predigrah, poigrah in medigrah. Ponekod se omenja še altovski glas, z besedico »alto« (gl. sliko 4), ki je v tem času pomenila tudi violo, vendar pa so ti zaznamki tu morda le kot opozorilo pri spremembi ključa (sopranskega v altovski).

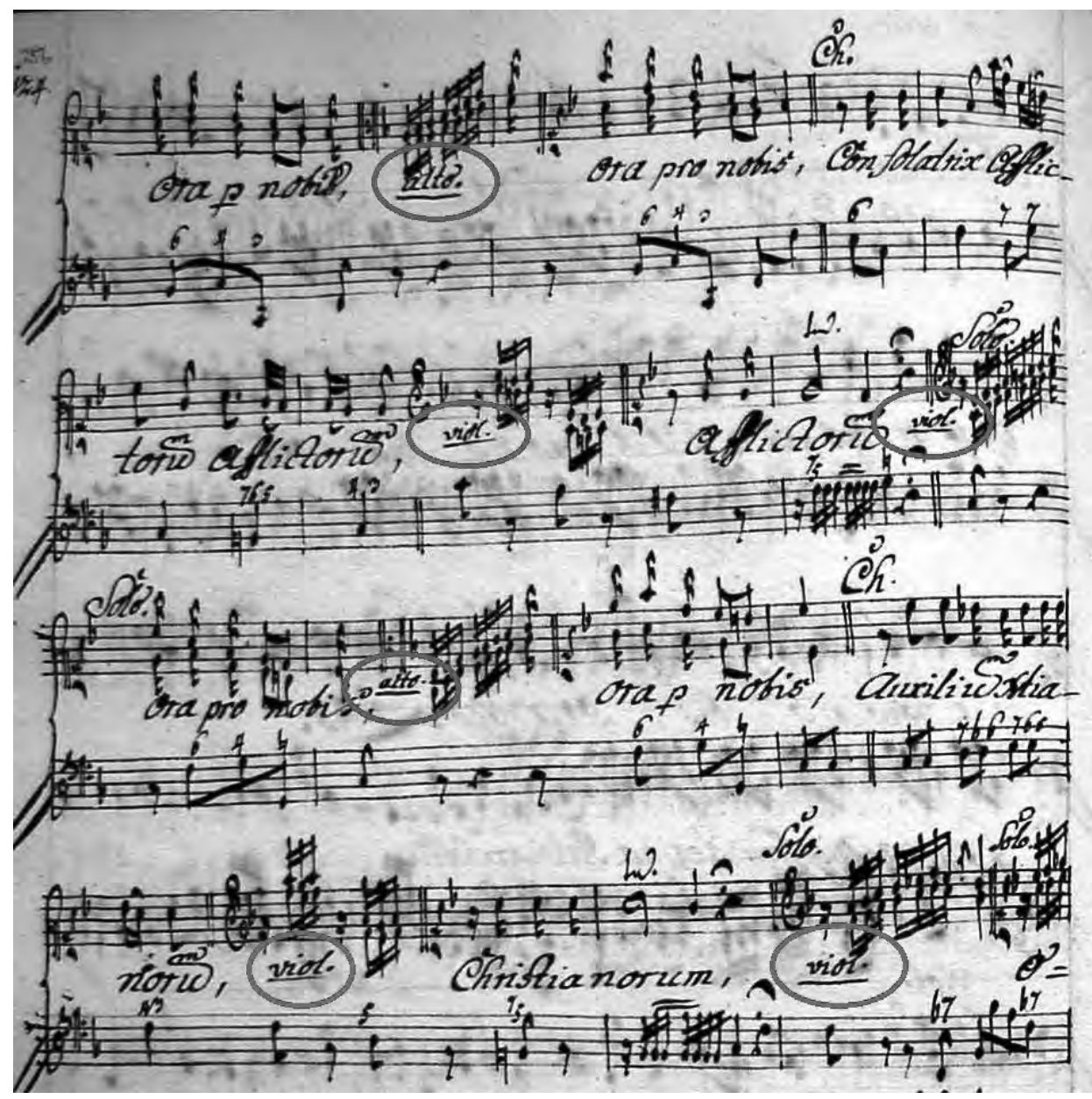

Slika 4

Oznake »alto« in »viol[ino]« v rokopisu SI-Nf, Ms. mus. 245, del strani 256 (Frančiškanski samostan Novo mesto, z dovoljenjem)

Preraščanje nekdanje skromnejše vloge godal (kot neobveznih instrumentov za spremljavo colla parte) v samostojnejše nastopanje obligatnega godalnega telesa, ki ga predpisuje Ms. mus. 245, je bilo posledica širših slogovnih sprememb v glasbi druge polovice 18. stoletja, natančneje, posledica krepitve načela koncertantnosti tudi v bolj poljudni cerkveni glasbi tistega obdobja na območju južnonemških in habsburških dežel. Enako velja za spreminjanje vloge orgel iz instrumenta za improvizacijo generalnega basa v glasbilo, ki v spremljavi ali solistično igra obligatni glas. To nazorno prikazujejo 
številni odlomki v Ms. mus. 245, ki vsebujejo izpisane nastope »rokokojskih orgel«, zelo značilnega elementa v cerkveni glasbi sredine in druge polovice 18. stoletja v avstrijskih in drugih južnonemških katoliških deželah (gl. sliko 5). ${ }^{15}$

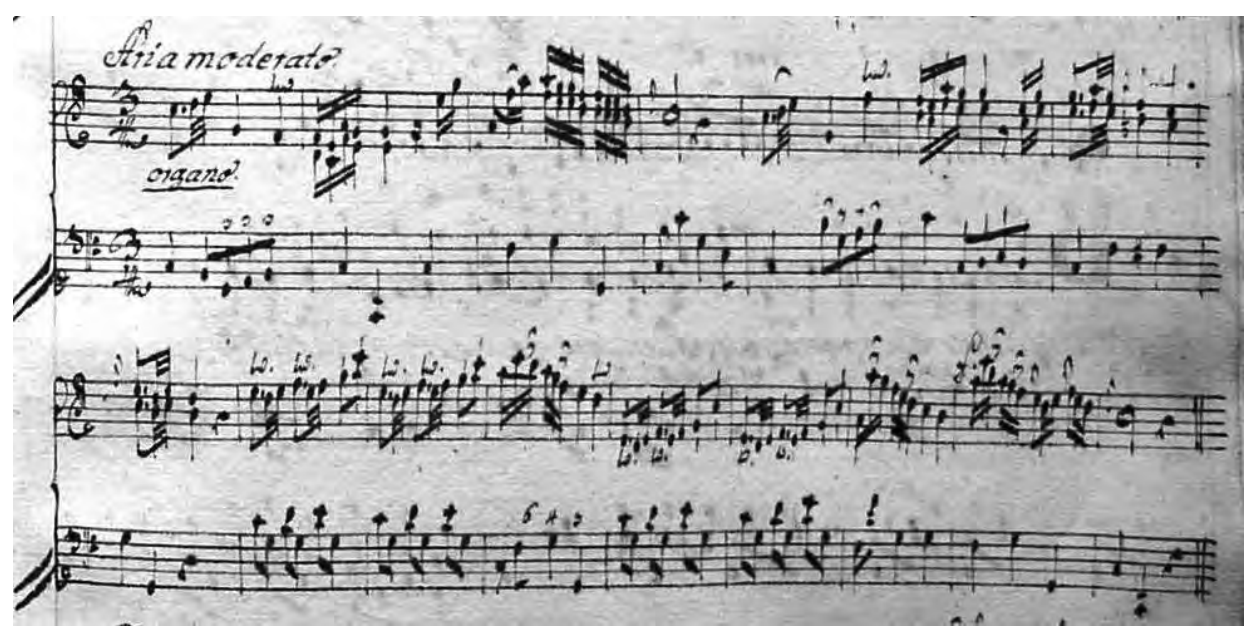

Slika 5

Odlomek obligatnih orgel v rokopisu SI-Nf, Ms. mus. 245, del strani 125 (Frančiškanski samostan Novo mesto, $\mathrm{z}$ dovoljenjem)

Zaradi že omenjene navedbe avtorstva ene od skladb v Ms. mus. 245, ki možnost nastanka knjige stavi v čas po šestdesetih letih 18. stoletja, in pravkar opisanih slogovnih značilnosti njenih kompozicij lahko s precejšnjo gotovostjo določimo ta rokopis kot najmlajše ali vsaj drugo najmlajše delo med vsemi obravnavanimi novomeškimi knjigami. Tako kot Ms. mus. 90 tudi Ms. mus. 245 zelo jasno sodi v tretje obdobje razvoja frančiškanske glasbe po izteku 17. stoletja. Ob večji slogovni enotnosti skladb ima Ms. mus. 245 - kljub obsegu kar 438 strani - zelo homogeno obliko; celega je zelo skrbno spisala ena sama roka. Zato so v njem verjetno le prepisi del iz drugih zbirk, in sicer petih maš, desetih kantat za različne cerkvene praznike, ki jih sestavljajo odlomki z recitativi, arijami in zbori, ter ene Stabat Mater, štirinajstih Marijinih litanij (med katerimi jih je kar devet z značilno »frančiškansko« sekvenco Si quaeris miracula na koncu skladbe) in enajstih Tantum ergo (glej tabelo 6).

Po svoji liturgični vsebini precej drugačna je knjiga Ms. mus. 90, saj vsebuje večinoma speve, ki slavijo Marijo in nima besedil mašnega ordinarija niti ne litanij (glej tabelo 1). Po svoji glasbeni vsebini je ta knjiga, kot že rečeno, zelo podobna Ms. mus. 245. Slogovno je relativno homogena in delo enega pisca, četudi nekatere grafološke podrobnosti (npr. sklepne vinjete na koncu skladb, gl. sliko 6) kažejo, da knjiga najverjetneje ni nastala naenkrat, temveč v več časovnih obdobjih; letnica 1775 na platnici je tako najbrž le čas njene vezave (gl. sliko 7).

${ }^{15}$ Prim. Olleson, »Church Music and Oratorio«, 313. 


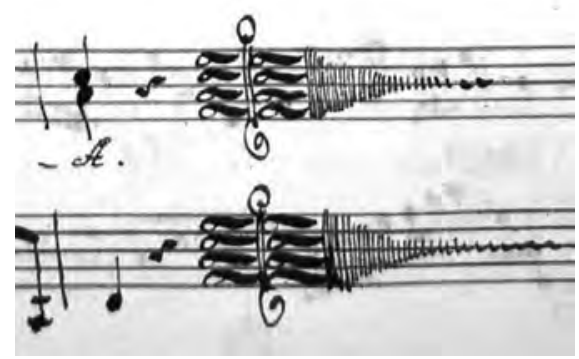

Skladbe 1-8

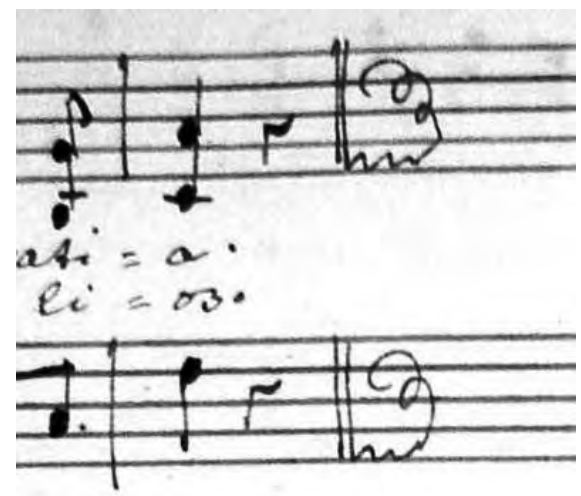

Skladbe 29-32

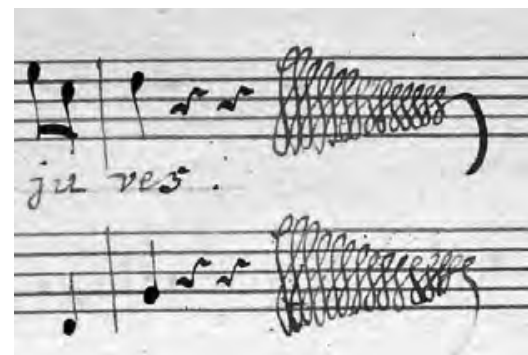

Skladbe 9-28

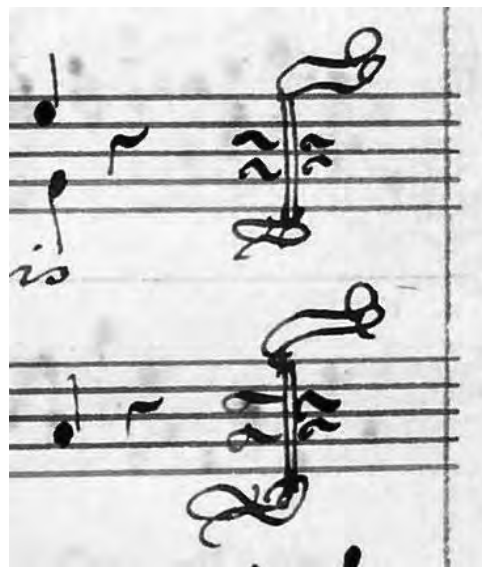

Skladbe 33-34

\section{Slika 6}

Vinjete ob koncu skladb v SI-Nf, Ms. mus. 90 (Frančiškanski samostan Novo mesto, z dovoljenjem)

Zanimiv je tudi preostali del napisa na platnici, ki je napisan z isto, zelo lepó oblikovano kaligrafijo kot notranjost knjige, saj pove, da je bila ta v osebni rabi p. Kalista Weibla. Weibl je bil po rodu Novomeščan, ki je po opravljenem noviciatu v Ljubljani študij teologije nadaljeval v Klanjcu (leta 1770), pozneje pa je ob p. Mavriciju Pöhmu (prav tako sposobnem organistu) deloval na koru novomeških frančiškanov vse do svoje smrti leta 1801, leta 1778 pa tudi kot organist samostanske cerkve na Trsatu. Danes je Weibl znan predvsem po zbirki krajših skladb za instrumente s tipkami, ohranjeni v klanjškem samostanu s signaturo C-94. Zbirka bi vsekakor lahko bila Weiblovo delo in je napisana $\mathrm{z}$ isto pisavo ter na enakem papirju kot njegova novomeška korna knjiga. ${ }^{16}$ Gre za papir še neznanega izvora $\mathrm{z}$ inicialkama AO v vodnem znaku, ki ju Einederjev katalog vodnih znakov 18. in 19. stoletja na območju nekdanjih habsburških dežel povezuje s češkim

${ }^{16}$ Več o Weiblovem in Pöhmovem življenju in delu v samostanih province sv. Križa gl.: Höfler, »Glasbenozgodovinske najdbe XVIII. in XIX. stoletja v Novem mestu«, 136-137; Kinderić, Franjevaci uz orgulje, 102-103 ter 106. 


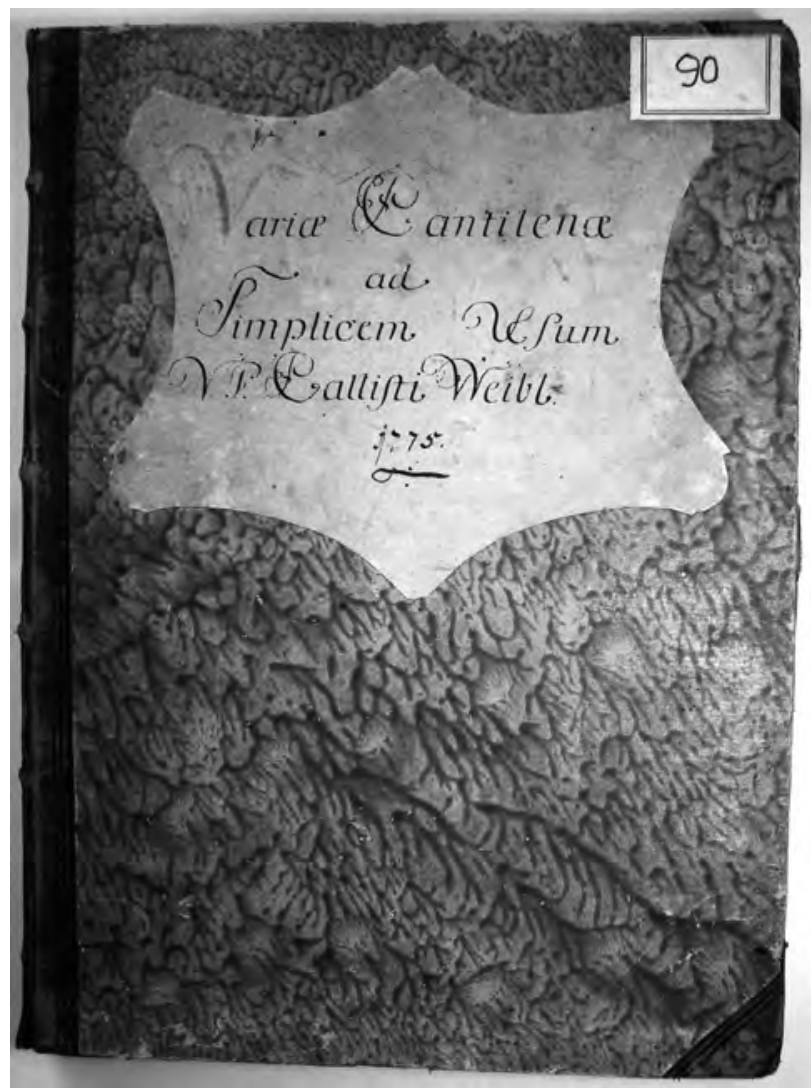

\section{Slika 7}

Platnica rokopisa SI-Nf, Ms. mus. 90 (Frančiškanski samostan Novo mesto, z dovoljenjem)

izdelovalcem Antonom Ossendorfom, ki pa je papirni mlin v Bensnu (Bensen) na Češkem prevzel šele okoli leta $1787 .{ }^{17}$

Glede na namen oziroma rabo razlikuje Kačic dva tipa frančiškanskih kornih knjig 18. stoletja. Po eni strani takšne, kot je Weiblova, ki so bile v osebni rabi redovnikov in so jih ti ob selitvah iz samostana v samostan jemali seboj. Drugi tip knjig, pri katerih pogosto zasledimo zaznamke, kot sta npr. »pro conventu« ali »pro choro conventu,« so rokopisi, ki so jih rabile različne generacije redovnikov v istem samostanu. Takšni sta v Novem mestu knjigi Ms. mus. 246 in Ms. mus. 247 z napisoma, ki nedvoumno razkrivata njun namen za rabo prav v novomeškem samostanu (glej sliko 8).

Tako kot Ms. mus. 91 in Ms. mus. 94 sta tudi obe zadnji knjigi napisani z zelo razpoznavno in po obliki nekoliko »neurejeno pisavo« (gl. sliki 2 in 9), ki jo je M. Barbo pri pregledu pisav v brežiškem Cantualu označil kot »manuproprij-L«. Čigava je bila ta pisava, zaenkrat ne vemo, srečamo pa jo še v drugih novomeških muzikalijah, denimo na rokopisnih vstavkih k tiskani zbirki maš op. 6 benediktinca Marianusa Königspergerja iz leta 1744 (gl. sliko 9).

Da je vse zadnje štiri omenjene novomeške korne knjige (Ms. mus. 91, 94, 246 in

${ }^{17}$ Prim. Eineder, The Ancient Paper-Mills of the Former Austro-Hungarian Empire and Their Watermarks, LVIII, XLVII in 114, 152-154. 


\section{Slika 8}

Zapis iz leta 1751 na prvi strani knjige SI-Nf, Ms. mus. 246 (Frančiškanski samostan Novo mesto, $\mathrm{z}$ dovoljenjem)
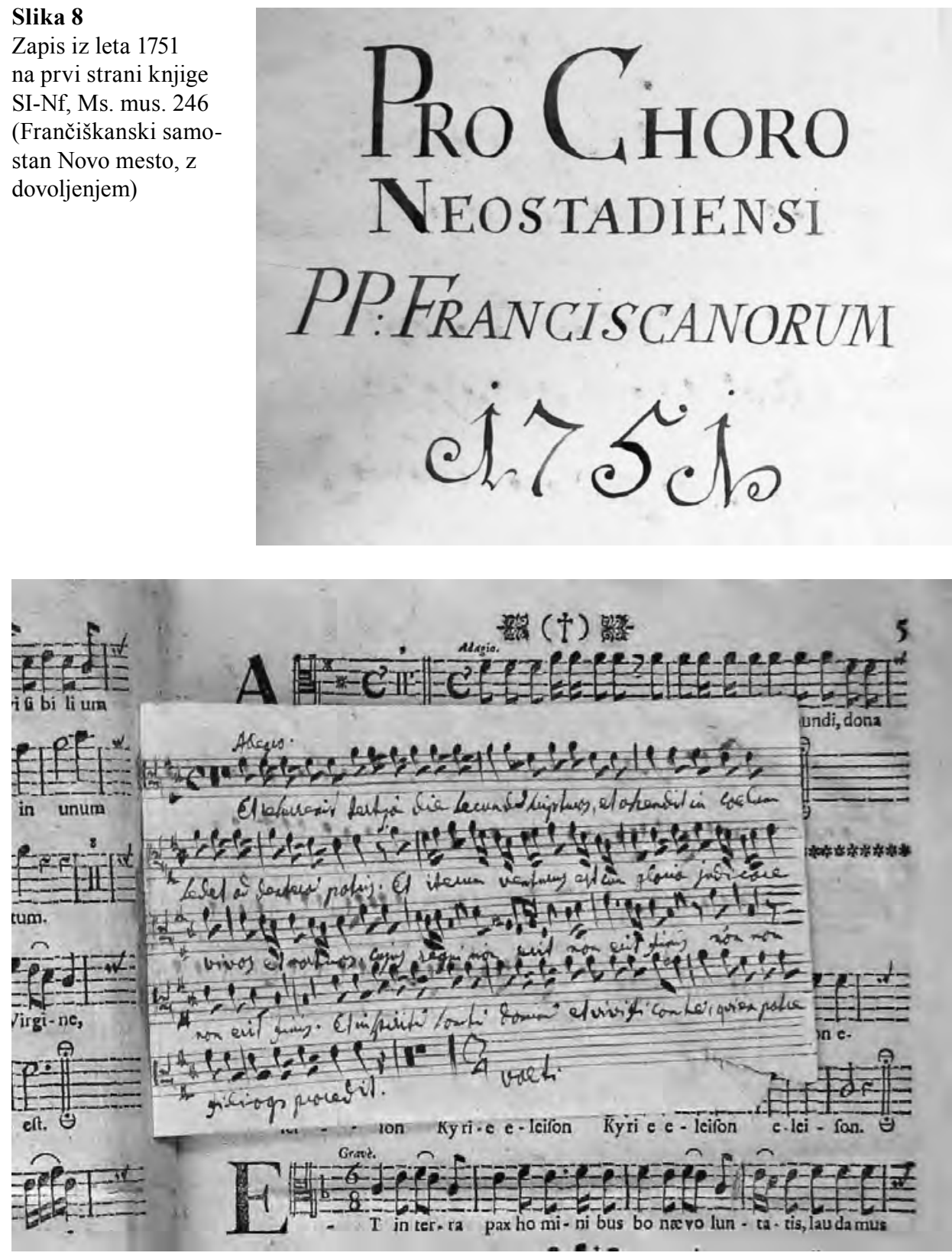

\section{Slika 9}

Rokopisni vstavek s pisavo »L« v Königspergerjevi zbirki SACRA RURIS DELICIÆ SEU SEX MISSA RURALES, op. 6, glasovni zvezek Alto, del strani 5, SI-Nf, T-329 (Frančiškanski samostan Novo mesto, z dovoljenjem) 
247) res potrebno obravnavati skupaj, kot razmeroma sklenjen opus frančiškanske glasbe v Novem mestu s sredine 18. stoletja, dokazujejo - poleg pisave - še druga dejstva:

1. Vodni znaki prostih listov v vezavi knjig Ms. mus. 91 in 247, ki so znamenje žužemberškega izdelovalca papirja Antona Nikla, so vsi iz štiridesetih let 18. stoletja (gl. sliko 10). ${ }^{18}$ To znamenje vsebuje tudi ves ostali papir v Ms. mus. 91, medtem ko je na papirju knjige Ms. mus. 247 le znak s tremi lunicami (brez inicialk), za katerega ni ugotovljeno lastništvo, vendar ga najdemo na več notranjih listih knjige Ms. mus. 246, datirane z letnico 1751 .
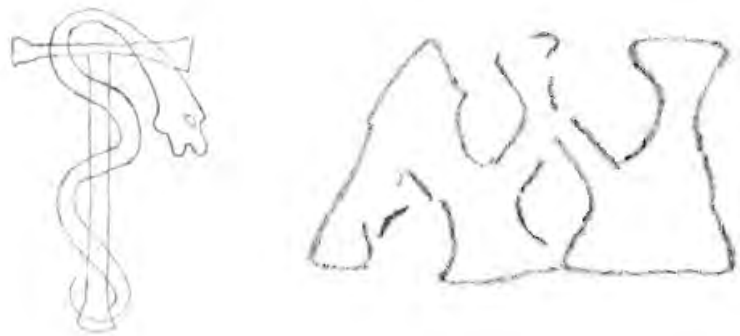

\section{Slika 10}

Vodni znak »kače na križu« z inicialkama AN na prostih listih v vezavi rokopisa SI-Nf, Ms. mus. 91 (Frančiškanski samostan Novo mesto, z dovoljenjem)

2. Omenjene štiri knjige se medsebojno dopolnjujejo tudi glede liturgične vsebine. Ms. mus. 91 vsebuje namreč vse vrste spevov, ki so običajni v takšnih rokopisih, razen maš, ki so v knjigi Ms. mus. 94. Enako velja za knjigi Ms. mus. 246 in 247 (glej tabele $2,5,7,8)$. Zato lahko sklepamo, da so bile posamezne knjige v tej skupini rokopisov že izvirno zamišljene kot del večje celote.

3. Te knjige so enotne tudi z ozirom na glasbeno vsebino, ki kaže slog, značilen za frančiškansko glasbo iz drugega obdobja njenega razvoja po koncu 17. stoletja, ko je tudi ta razmeroma avtonomen del cerkvene glasbe 18. stoletja v večji meri začel sprejemati načela koncertantnosti in sodobne kantatne glasbe. V primerjavi z mlajšima novomeškima knjigama (Ms. mus. 90 in 245) knjige Ms. mus. 91, 94, 246 in 247 zelo jasno razkrivajo nekatere skupne značilnosti frančiškanskih skladb iz prve polovice 18. stoletja z območja srednje Evrope, kot je na primer dosledno enoglasni zapis vokalnega parta, ki se je sicer izvajal z več vokalnimi glasovi. Kot je bilo že omenjeno, so ponekod v partituri nad pevsko melodijo, zapisano v sopranskem ključu, zaporedni zapisi besed »Solo Alto«, »Canto Solo« in »Tenor Solo«. Solistični in zborovski deli se v teh skladbah izmenjujejo počasneje kot v skladbah iz knjig Ms. mus. 90 in 245, pogosteje pa vsebujejo nekatere za starejšo glasbo bolj značilne menzure, npr. za 3/2 in 6/4 takt. V teh skladbah tudi še ni t. i. »rokokojskega« izmenjevanja duol s triolami v melodiji ipd.

Zelo podoben slog kažejo tudi skladbe v rokopisu Ms. mus. 92, ki so uglasbitve besedil za različne cerkvene praznike (glej tabelo 3). Začetnih 34 strani rokopisa (od skupno 138 strani) predstavlja morda celo najstarejši segment frančiškanske glasbe novomeških kornih

${ }^{18}$ Prim. Šorn, »Starejši mlini za papir na Slovenskem«, 107 in 114-115. 
knjig, saj mu na njegovi zadnji strani (še zmeraj v začetnem delu knjige) neposredno sledi del, ki je spet napisan s pisavo »L«. Niti izvor papirja niti lastništvo pisave v prvem delu Ms. mus. 92 zaenkrat še nista znana.

Še nekoliko bolj nejasen je izvor knjige Ms. mus. 93. To je sicer vso napisala ista roka, vendar verjetno ne naenkrat, saj se pisava $v$ posameznih delih knjige tudi nekoliko spreminja. Pri tem je posebno zanimivo, da spremembe v pisavi precej tesno sledijo spremembam sloga; glasba v knjigi kaže tako značilnosti vseh treh omenjenih slogovnih obdobij frančiškanske glasbe: prvega s konca 17. stoletja (gl. sliko 11), drugega iz prve polovice 18. stoletja (gl. Sliko 12) in tretjega iz druge polovice 18. stoletja (gl. sliko 13). ${ }^{19}$

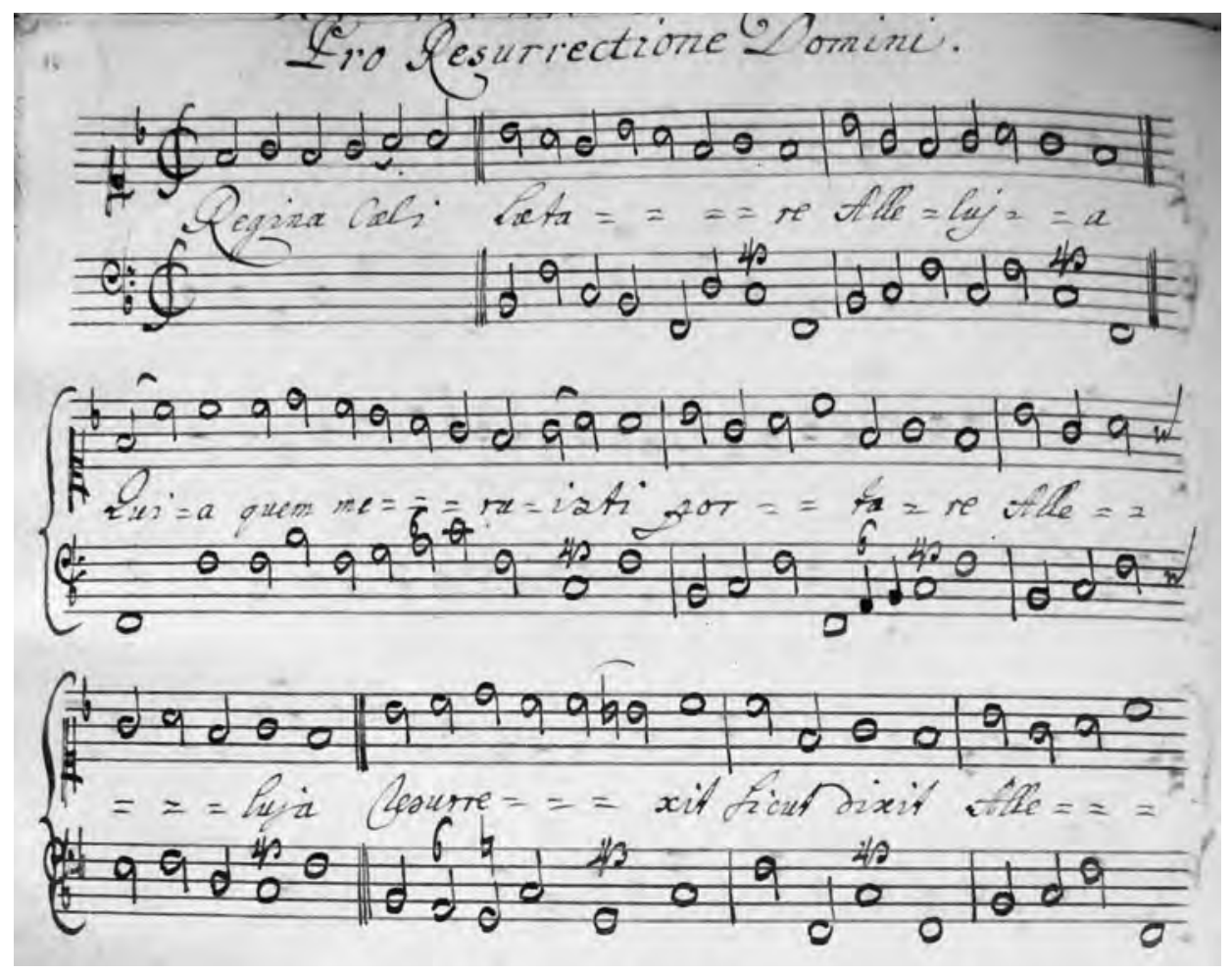

\section{Slika 11}

Primer frančiškanske glasbe v slogu s konca 17. stoletja; del strani 16 v rokopisu SI-Nf, Ms. mus. 93 (Frančiškanski samostan Novo mesto, z dovoljenjem)

Sodeč po vodnem znamenju na prostih listov vezave (gl. sliko 14) je bila knjiga Ms. mus. 93 v celoto povezana šele po začetku sedemdesetih leti 18. stoletja, saj je to znamenje znak koroškega izdelovalca papirja Georga Tengga iz okoli leta $1771 .{ }^{20}$ Knjiga vsebuje

${ }^{19}$ Podrobnejši opis slogovnih značilnosti frančiškanskih skladb v teh obdobjih podaja Grasemann, »Die Franziskanermesse des 17. und 18. Jahrhunderts«, povzetki na staneh 80-82, 100-102 in 108-112.

${ }^{20}$ Eineder, The Ancient Paper-Mills of the Former Austro-Hungarian Empire and Their Watermarks, vodni znak št. 738 (slika 196). 


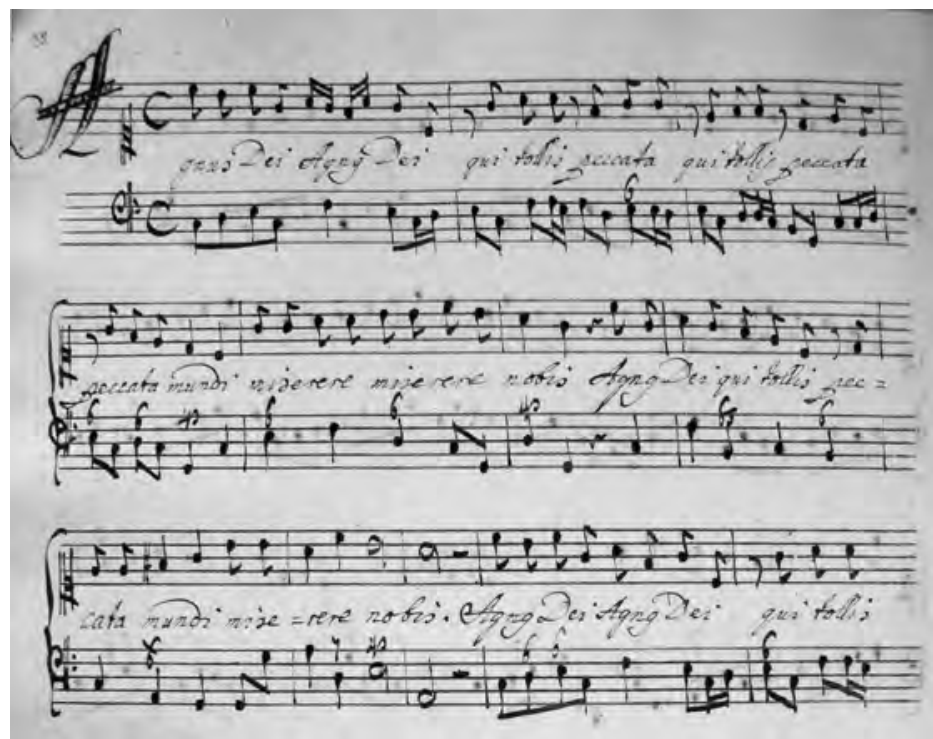

\section{Slika 12}

Primer frančiškanske glasbe v slogu prve polovice 18. stoletja; del strani $38 \mathrm{v}$ rokopisu SI-Nf, Ms. mus. 93 (Frančiškanski samostan Novo mesto, $\mathrm{z}$ dovoljenjem)

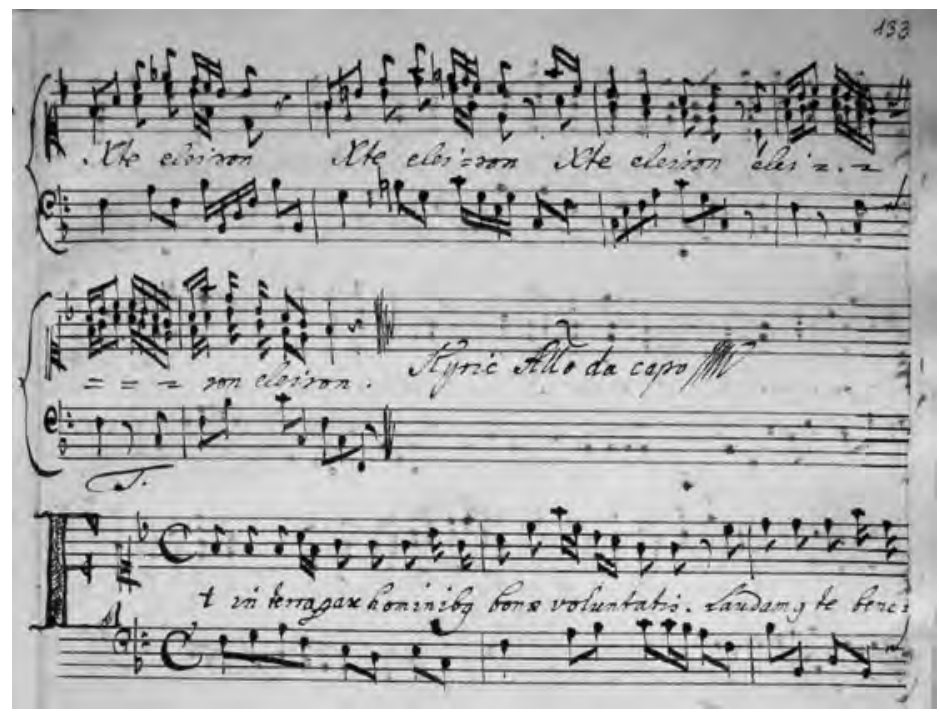

\section{Slika 13}

Primer frančiškanske glasbe v slogu druge polovice 18. stoletja; del strani 133 v rokopisu SI-Nf, Ms. mus 93 (Frančiškanski samostan Novo mesto, $\mathrm{z}$ dovoljenjem)

vse vrste spevov, ki sestavljajo repertoar t. i. »Opusa franciscanum« v srednji Evropi med koncem 17 in koncem 18. stoletja (motete za različne cerkvene praznike, Marijine antifone, litanije, maše in speve za pokojne); najbrž je zbirka skladb in večglasnih spevov, prepisanih v različnem času iz več različno starih frančiškanskih kornih knjig.

Spričo obsega in pestrosti glasbenega repertoarja $v$ obravnavanih novomeških knjigah ter njihovega števila, visokega $\mathrm{z}$ ozirom na to, da izhajajo le iz enega samostana, lahko domnevamo, da je bila glasba frančiškanskih redovnikov v 18. stoletju pri nas izjemno živa. S svojim načinom uglasbitev cerkvenih besedil je ustrezala okusu preprostejših ljudi, ki so skupaj s frančiškanskimi redovniki sodelovali pri raznih verskih obredih in 

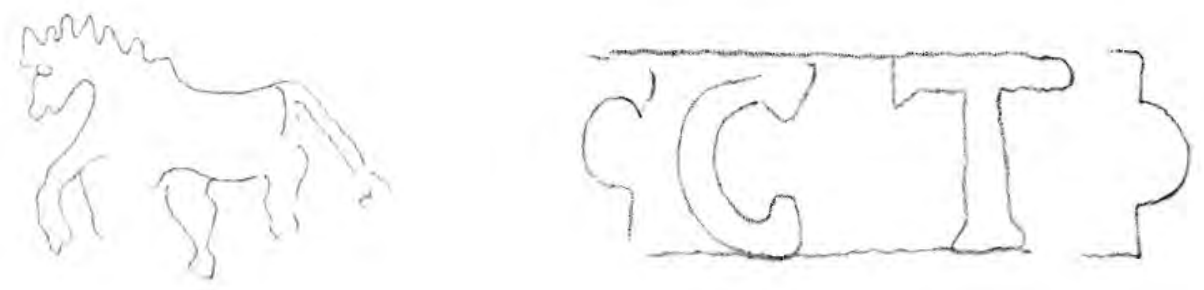

\section{Slika 14}

Vodni znak »konjička« z inicialkami GCT na neprostih listih vezave rokopisa SI-Nf, Ms. mus. 93 (Frančiškanski samostan Novo mesto, z dovoljenjem)

praznovanjih. Bila je torej pomemben del glasbenega življenja v cerkvah, ki je bilo tedaj zelo raznoliko ne samo v verskem, temveč tudi v glasbeno-sociološkem pogledu. Zato bosta temu prvemu pregledu osmih novomeških rokopisov - ki je prikazal nekaj tipičnih značilnosti glede vsebine in izvora rokopisov ter s tem njihovo pripadnost posebni praksi gojenja glasbe v srednjeevropskih frančiškanskih samostanih med koncem 17. in začetkom 19. stoletja - v prihodnje morali slediti še bolj podrobna analiza glasbene in tekstovne vsebine skladb, ki jih ti rokopisi vsebujejo, ter njihova neposredna primerjava s frančiškansko glasbo v drugih glasbenih zbirkah tega obdobja na območju srednje Evrope. Šele oboje bo pokazalo pravo zgodovinsko in estetsko vrednost do sedaj skoraj povsem spregledanega repertoarja glasbe 18. stoletja na slovenskih tleh.

Tabela 1: vsebina rokopisa SI-Nf, Ms. mus. 90

Salve Regina [in G]

Salve Regina [in F]

Salve Regina [in F]

Trophaea canite fideles animae [in C]

Venite laetantes adeste ovantes [in C]

Salve mundi Domina caelorum Regina [in C]

Caeli cives ad laudes currite [in A]

Gaudete iusti in Domino gaudete [in A]

Pro Dominicis per annum / Dextera Domini fecit virtutem [in B]

Immaculata et pia o Virgo Mater [in B]

Regina coeli [in D]

Ave virgo gloriosa [in F]

Ave Regina coelorum [in C]

Deus meus amor meus [in A]

Pia Mater intuere [in B]

Amor amor mea vita [in F]

O Manna cordium [in G]

Sionis filiae coelestes nimphulae [in G]

Regina caeli [in C]

Regina coeli [in G]
Regina coeli [in G]

$\mathrm{O}$ mi Jesu amate [in A]

Peccavi Domino sum indignus [in G]

Salve Regina [in F]

Regina coeli [in C]

Popule meus quid feci tibi [in g]

Stabat Mater [in F]

Stabat Mater [in C]

Mariae Matris Virginis clientes mecum canite [in F]

Ave Virgo singularis [in B]

Salve Mater pietatis [in F]

Salve Virgo salutata [in B]

Verbum supernum prodiens [in $\mathrm{C}$ ]

Stabat Mater [in F]

Stabat Mater [in B]

Regina coeli [in C]

Regina coeli [in C]

Ach quis nos separabit [in G]

Salve Jesu pastor bone [in F] 
Tabela 2: vsebina rokopisa SI-Nf, Ms. mus. 91

[Litanije v C]

[Litanije v C]

[Litanije $v$ C]

[Litanije v C]

[Litanije v D]

[Litanije v G]

[Litanije v E]

[Litanije v B]

Tota pulchra [in F]

Tota pulchra [in c]

Tota pulchra [in g]

Tota pulchra [in B]

Tota pulchra [in G]

Tota pulchra [in c]

Tota pulchra [in F]

Tota pulchra [in g]

Tota pulchra [in F]

Tota pulchra [in G]
Tota pulchra [in D]

Tota pulchra [in E]

[Litanije v G]

[Litanije v F]

[Litanije v F]

[Litanije v B]

Alma redemptoris Mater [in D]

Alma redemptoris Mater [in F]

Ave Regina caelorum [in G]

Regina coeli [in G]

Regina coeli [in G]

Regina coeli [in A]

Salve Regina [in G]

Salve Regina [in F]

[Rekviem v c]

Tabela 3: vsebina rokopisa SI-Nf, Ms. mus. 92

Pro Sanctis Apostolis vel Martyribus / Sancti et justi in Domino [in A]

Pro omni tempore / Magnus Dominus magnus et laudabilis [in B]

Pro omni tempore / Confitebor tibi [in E]

Pro uno Sancto / Domine iste Sanctus habitabit [in B]

De Communi Apostolorum Vel unius Martyris aut Confessoris / Beatus vir [in B]

Pro Virgine, vel Pro nec Virgine nec Martyre / Veni electa et ponam in te [in A]

Pro omni tempore / Recit:: Ah! cor quid hic deperis [in F] - Aria: Nolo vivere absque [in F]

De S. Spiritu / Veni Sancte Spiritus [in C]

De B. Virgine Maria / Salve Virgo benedicta [in A]

Pro Resurrectione Domini / Surrexit Dominus Deus [in D]

De SS. Trinitate / Benedictus sit dei Pater Deus [in E]

De SS. Trinitate / Gratias tibi deus [in D]

De Tempore / De profundis [in c]

De S. Spiritu / Veni Sancte Spiritus [in B]
Pro Dominicis per annum / Dextera Domini fecit [in B]

Pro omni tempore, sive Mobilibus festis / Tua est potentia [in D]

De B. V. Maria Immaculata / Immaculata et pia virgo Mater [in B]

De B. V. Maria / Ave virgo gloriosa [in F]

De B. V. Maria / Ave Regina coelorum [in C]

De B. V. Maria / Regina coeli [in D]

De pluribus Martyribus / Gaudete iusti in Domino [in A]

Pro uno Martyre / Iste sanctus pro lege dei [in G]

Pro Confessore Pontifice / Ecce sacerdos magnus [in e]

Pro Quocunqe Sancto / Gloria et honore coronasti [in D]

Pro Quocunqe Sancto, vel Sancta / Gaudeamus omnes [in C]

De Tempore / Quid moraris [in F]

De SS. Sacramento / Dulce cordis epulum [in D]

De vanitate mundi pro omni tempore / Recit.: Vanitatum vanitas [in C] - Aria: Terrena cur amas [in C] 
De B. V. Maria / Gaude virgo gloriosa [in D] Pro Confessoribus / Euge serve bone [in D]

De S. Chatarina vel Alia Sancta / Convolate, festivate [in B]
De Sanctis Mulieribus / Huc o bellae sortis stellae [in Es]

De festis Mobilibus / Diem festum celebrate [in C] De festis Mobilibus / Plaudite coelites [in C] De Tempore / Aurea tella dulcia bella [in C]

Tabela 4: vsebina rokopisa SI-Nf, Ms. mus. 93

Dixit Dominus Domino meo, Confitebor tibi, Beatus Vir, Laudate pueri, Laudate Dominum, Magnificat, In exitu Israel (v osmih tonusih in $\mathrm{v}$ tonusu peregrinus)

Te deum laudamus, Te Aeternam, Sanctus, Pleni sunt, Tu Rex, Te ergo quaesumus, Salvum fac, Per Singulos dies, Benedicimus te, Dignare Domine (samo generalni bas)

Hymnus pro SS. Apostolis / Exultet orbis gaudiis Pro uno Martyre / Deus tuorum

Pro Martyribus, S. Josepho ac SS. Angelis / Sanctorum meritis

Pro Confesoribus, ac S. Joanne Baptista / Iste confessor Domini

Pro Virginibus, et Viduis / Jesu corona Virginum

Pro Dedicatione, festo Corporis Christi, ac

SS. Stigmatum / Caelestis urbs Jerusalem

Pro festis B. V. Mariae / Ave maris Stella

Pro Adventu / Creator alme siderum [in Es]

In festis Nativitatis, Circumcisionis D.N.I.C.,

SS. Innocentum et SS. Omnium / Jesu

Redemptor omnium

In Epiphania Domini / Crudelis Herodes

Audi benigne Conditor

In Dominica Passionis / Vexilla regis

Tempore Paschali / Ad regias agni dapes

Pro Ascensione, festo SS. Nominis Jesu, et

Transfiguratione / Salutis humanae sator Jesu

Pro Pentecoste / Veni Creator spiritus

Pro festo SSmae Trinitatis, ac pro Sabbatis / Iam sol recedit igneus

In Dominicis per annum / Lucis Creator

In festo S. Antonii Paduani ac festis Ordinis / En gratulemur hodie

In festo S. Paschalis, ac aliis Ordinis / Laeta devote celebret
In secundis Vesp. S. P. Francisci / Decus morum dux minorum

In festo S. Clarae / Concinat plebs fidelium

In festo S. Raphaelis / Tibi Christe, splendor patris

In festo S. Michaelis / Te splendor et virtus patris

In Apparitione S. Michaelis / Te splendor et virtus patris

S. Petri ad Vincula / Miris modis repente

In utraque Cathedra S. Petri / Quodcunque in orbe nexibus

Pro Resurrectione Domini / Regina caeli

Pro Adventu / Rorate

[Maša v C]

[Maša $v$ C]

[Maša v C]

[Maša v B]

[Maša $v$ B]

[Maša v B]

[Maša v G]

[Maša v G]

[Maša v G]

[Maša v D]

[Maša v D]

[Maša v A]

[Maša v F]

[Maša v B]

[Maša v G]

Litaniae de S. Antonio [in D] (s sekvenco Si quaeris miracula)

Tantum ergo [in D]

Tantum ergo [in C]

Tantum ergo [in G]

Pro diebus Sabbatinis / Stella caeli

Stella caeli [in C] 
[Rekviem v 7. tonusu]

[Rekviem v Es]

[Rekviem v Es]
[Rekviem v Es]

Offertorium / Domine Jesu Christe [in Es]

Tabela 5: vsebina rokopisa SI-Nf, Ms. mus. 94

[Maša v B]

[Maša $v \mathrm{~F}$ ]

[Maša v G]

[Maša v B]

Natalitium [Maša v F]

[Maša v A]
[Maša v A]

[Maša $v$ E]

Rorate caeli [in G] - Psalmus / Caeli enarrant gloriam Dei

Tabela 6: vsebina rokopisa SI-Nf, Ms. mus. 245

Missa Sancti Aviti Martyris [in C]

[Missa] S. Expediti Martyris [in C]

[Missa] S. Georgii Martyris et Equitis [in G]

Missa Sancti Flavii [in D]

[Maša v c]

Pro feria II. Paschatis / Recit.: Qui sunt hi sermones - Solo Canto: O vos stulti-Chorus: Dies jam advesperascit

De Communi Confessoris non Pontificis / Recit.: Beatus vir

De B. V. Maria / Recit:: O me felicem

De SS. Apostolis / Recit.: Potestis Charissimi

Recitative: Bonum mihi quia humiliasti me

Recitative: Custodit Dominus omnes

Recitative: In te confirmatus sum

De S. Michaele, vel Raphaele Archang. / Recit.:

Princeps gloriosissime

Offertorium Pastoritium / Quem vidistis Pastores

Recit:: Infelix ego

Stabat Mater [in Es]

S. Petri Chrystologi Episcopi \& ecclesiae Doctoris / [Litanije v C]

[Litanije v D]

[Litanije v D]
[Litanije v G s sekvenco Si quaeris miracula]

[Litanije v C s sekvenco Si quaeris miracula]

[Litanije v C s sekvenco Si quaeris miracula]

[Litanije v D s sekvenco Si quaeris miracula]

[Litanije v D s sekvenco Si quaeris miracula]

[Litanije v C s sekvenco Si quaeris miracula]

[Litanije v C s sekvenco Si quaeris miracula]

S. Antonii Paduani Confessoris I. Ordinis

[Litanije v D s sekvenco Si quaeris miracula]

S. Francisci Seraph. III. Ordinis fundatoris [Litanije v D s sekvenco Si quaeris miracula]

[Litanije v F]

Lythaniae Pastoritae [in F]

Tantum ergo [in G]

Tantum ergo [in F]

Tantum ergo [in D]

Tantum ergo [in E]

Tantum ergo [in F]

Tantum ergo [in B]

Tantum ergo [in F]

Tantum ergo [in G]

Tantum ergo [in $\mathrm{C}$ ]

Tantum ergo [in A]

Tantum ergo [in C]

Tabela 7: vsebina rokopisa SI-Nf, Ms. mus. 246

[Maša v A]

[Maša v D]

[Maša v F]

[Maša v C] 


$\begin{array}{ll}{[\text { Maša } v \text { B }]} & {[\text { Maša } v \text { g] }} \\ {[\text { Maša } v \text { Es }]} & {[\text { Maša } v \text { B] }} \\ {[\text { Maša } v \text { A }]} & {[\text { Maša } v \text { G] }} \\ {[\text { Maša } v \text { A }]} & {[\text { Maša } v \text { A] }} \\ {[\text { Maša } v \text { G] }} & {[\text { Maša } v \text { D] }} \\ {[\text { Maša } v \text { B }]} & {[\text { Maša } v \text { G] }} \\ {[\text { Maša } v \text { C }]} & \text { Sacrum pro Natalitiis Festis [Maša } v \text { E] }\end{array}$

Tabela 8: vsebina rokopisa SI-Nf, Ms. mus. 247

Tantum ergo [in G]

Tantum ergo [in C]

Tantum ergo [in D]

De SS. Trinitate / Benedictus [in E]

De SS. Sacramento / O salutaris hostia [in c]

De Spiritu Sancto / Veni Sancte Spiritus [in B]

De SS. Trinitate / Gratias tibi Deus [in D]

Pro festo Immaculatae Conceptionis / Immaculata et pia o Virgo Mater [in B]

De B. V. Maria / Ave virgo gloriosa [in F]

De Beate Virgine Maria / Ave Regina coelorum [in C]

De Beate V. Maria / Regina coeli [in D]

De Immaculata Conceptione B. V. / Sanca et immaculata [in A]

De Apostolis / Estote fortes in bello [in C]

De Apostolis, vel Martyribus / Sancti et justi [in A]

Pro pluribus Martyribus / Gaudete iusti in Domino [in A]

Pro uno Martyre / Iste Sanctus pro lege [in G]

Pro Confessore Pontifice / Ecce sacerdos magnus [in e]

Pro Confessore non Pontifice / Iustus germinabit [in A]

Pro Quocunqe Sancto / Gloria et honore coronasti [in D]

Pro Quocunqe Sancto, vel Sancta / Gaudeamus omnes [in C]

Pro Quolibet Sancto / Domine iste sanctus [in D]

Pro Quovis Sancto / Domine iste sanctus [in B]

Pro uno Martyre / Beatus vir [in B]

Pro Virginibus / Veni sponsa Christi [in F]

Pro Virginibus, Vel SS. Mulieribus / Veni electa [in F]
Pro omni Tempore / Confitebor tibi [in E]

De Tempore pro Dominicis / De profundis [in E]

Pro Dominicis per Annum / Dextera Domini fecit virtutem [in B]

Pro omni Tempore / Tua est potentia [in D]

Pro festis Mobilibus / Haec est Dies [in C]

[Rekviem v g]

[Rekviem v g]

[Litanije v Es]

[Litanije $\mathrm{v}$ c]

[Litanije v B]

[Litanije v C]

[Litanije v B]

[Litanije v B]

[Litanije v B]

[Litanije v C]

[Litanije v C]

[Litanije v Es]

[Litanije v c]

[Litanije v Es]

[Litanije v B]

[Litanije v B]

[Litanije v G]

[Litanije $\mathrm{v}$ a]

[Litanije $\mathrm{v}$ a]

[Litanije $\mathrm{v} g$ ]

[Litanije $v \mathrm{~g}$ ]

[Litanije v D]

[Litanije v Es]

[Litanije v F]

[Litanije $\mathrm{v}$ g]

[Litanije in c]

Salve Mater gratiosa [in B] 


\author{
Stella coeli [in B] \\ O serenissima, o clementissima [in B] \\ Salve virgo gloriosa [in D] \\ Grata virgo Nazarea [in B] \\ $\mathrm{O}$ virgo Maria [in F] \\ Maria tu nostra fidissima spes [in G] \\ Mariam amare est coelitum dos [in B] \\ O Maria mater pia [in A] \\ Maria virgo ave [in D] \\ Virgo salve [in G] \\ Virgo Maria patrona pia [in D] \\ Ah quis binas columbinas [in $\mathrm{F}$ ] \\ Anima par coelo spiritus [in F]
}

\author{
$\mathrm{O}$ amor! quo vocas, quo adicis me! [in $\mathrm{F}$ ] \\ Sponte mi, defessa lacrimis [in F] \\ Quis me Jesu liberabit [in D] \\ Fons amoris Jesu pie [in Es] \\ O Jesu, o amor, dulcissima spes [in D] \\ Sola salus est in cruce [in Es] \\ [Litanije v e] \\ [Litanije v D] \\ [Litanije $\mathrm{v}$ C] \\ [Litanije v C] \\ Tota pulchra [in B]
}

\section{Uporabljena literatura}

Barbo, Matjaž. »'Cantual' brežiškega frančiškanskega samostana«. V: S patri smo si bili dobri. Tri stoletja brežiških frančiškanov, ur. Jože Škofljanec, 257-273. Krško: Zavod Neviodunum, Ljubljana: Brat Frančišek, 2013.

Benedik, Metod. »Protireformacija in katoliška prenova«. V: Zgodovina cerkve na Slovenskem, ur. Metod Benedik, 113-152. Celje: Mohorjeva družba, 1991.

Dotzauer, Wilfried. »Die kirchenmusikalischen Werke Johann Valentin Rathgebers«. Dokt. dis., Friedrich-Alexander-Universität, Erlangen-Nürnberg, 1976.

Eineder, Georg. The Ancient Paper-Mills of the Former Austro-Hungarian Empire and Their Watermarks. Monumenta chartae papyraceae historiam illustrantia. Zv. 8. Hilversum: Paper Publications Soc., 1960.

Grasemann, Friederike. »Die Franziskanermesse des 17. und 18. Jahrhunderts«. Studien zur Musikwissenschaft 27 (1966): 72-124.

Höfler, Janez. »Glasbenozgodovinske najdbe XVIII. in XIX. stoletja v Novem mestu«. Kronika 15, št. 3 (1967): 135- 148.

Kačic, Ladislav. »Figuralmusik der Franziskaner in Mitteleuropa - Repertoire und Aufführungspraxis«. V: Musik und Kultur der geistlichen Orden in Mitteleuropa zwischen Tridentinum und Josephinismus (interdisziplinäre WWW-Konferenz), ur. Ladislav Kačic, 163-174. Bratislava: Slowakische Akademie der Wissenschaften, Kabinet für Slawistik, 1997.

___ . »Mehrstimmiger Gesang der Franziskaner in Mitteleuropa im 17. Jahrhundert«. Slovenská hudba 22, št. 3-4 (1996): 450-454.

___ . »Missa franciscana der Marianischen Provinz im 17. und 18. Jahrhundert«. Studia Musicologica Academiae Scientiarum Hungaricae 33 (1991): 5-107.

____ „ »'Opus franciscanum' v zápise a zvukovnej podobe«. Slovenská hudba 18, št. 1 (1992): 136-145.

Kinderić, Petar Antun. Franjevaci uz orgulje. Krapina: Hrvatsko društvo crkvenih glazbenika, 2006.

Lipowsky, Felix Joseph. Baierisches Künsler-Lexikon. 2 zv. München, 1810. 
Olleson, Edward. »Church Music and Oratorio«. V: The New Oxford History of Music. Zv. 7, The Age of Enlightenment, ur. Egon Wellesz in Frederick Sternfeld, 288-335. London: Oxford University Press, 1973.

Popis muzikalija u Knjižnici franjevačkog samostana u Samoboru. Ur. Ladislav Šaban, Svanibor Pettan in Ivan Lončar (tipkopis, julij 1981).

Richter, Pál. Der Melodienbestand des Franziskanerordens im Karpatenbecken im 17. Jh. Fontes historici ordinis fratrum minorum in Hungaria, zv. 4. Budimpešta: Magyarok Nagyasszonyáról Nevezett Ferences Rendtartomány, 2007.

Riman, Marija. »Barokna glazba u franjevačkom samostanu na Trasatu u Rijeci«. Arti musices 28, št. 1-2 (1997): 19-34.

Škofljanec, Jože. »Red manjših bratov (O. F. M.) in provinca sv. Križa«. V: Frančiškani v Ljubljani: samostan, cerkev in župnija Marijinega oznanjenja, ur. Silvin Krajnc, 9-77. Ljubljana: Samostan in župnija Marijinega oznanjenja, 2000.

Šorn, Jože. »Starejši mlini za papir na Slovenskem«. Zgodovinski časopis 8, št. 1-4 (1954): 87-117.

\section{FRANCISCAN EIGHTEENTH-CENTURY CHOIR BOOKS FROM NOVO MESTO}

\section{Summary}

This article discusses eight eighteenth-century Franciscan manuscripts in Novo mesto (SI-Nf, Ms. mus. 90-94 and 245-247). Their musical and textual contents show some fundamental characteristics of a specific musical repertoire used by Franciscans during the eighteenth century in central Europe. The first of these is the prevailing anonymity of compositions preserved in musical sources now described as "Franciscan choir books," despite the fact that these books were originally designed not for choral singers but for organists, as leading figures in performing music in Franciscan churches. For this reason, the compositions in books like these are mostly written down in the manner of organ music; that is, as particello: with one or two soprano voices (Canto) in the upper stave, the organ continuo part in the lower stave, and the lyrics between the two. Among all the Franciscan choir books in Novo mesto only Ms. mus. 245 contains some noteworthy digressions in this respect. For example, it contains fragments notated in three staves as well as sections in which the participation of two violins and organo obbligato is required. One composition in this book (Litanies in C major) is a work by Bavarian monk Peter Chrysologus Pachmayr; the others are anonymous, just like the repertoire (motets, antiphons, masses, litanies, and requiems) in the seven remaining Franciscan books in Novo mesto.

In addition to Ms. mus. 245, Ms. mus. 90 also reflects a musical style that is typical of the "third period" of development of Franciscan music between the late seventeenth and the beginning of the nineteenth century (Friederike Grasemann). The inscription in the front of the book discloses the year of its compilation and the name of its owner. The book was completed in 1775 and it was in the personal use ("Ad Simplicem Usum") of Callistus Weibl, a Franciscan friar and organist in Novo mesto in the late eighteenth century. 
Regarding their manner of usage, manuscripts Ms. mus. 246 and 247 represent a different type of Franciscan choir books in the eighteenth century; that is, books that were originally composed not for one particular individual but for a monastery and its choir as a music institution. They remained in that monastery for a longer period of time and they were used there by several generations of friars. The remarks "Pro Choro Neostadiensi" on the first pages of Ms. mus. 246 and 247 clearly reflect this sort of "non-individual" usage. The first book was composed in 1751. Together with the second one it belongs to the group of four manuscripts (Ms. mus. 91, 94, 246 and 247) that were all written in the same hand and all originated - judging by the watermarks in their paper - in the fourth or fifth decennium of the eighteenth century. Consequently, the compositions in these four books reveal the style of Franciscan music from its "second period" of development (i.e., from the first half of the eighteenth century). They are written in a score with only one vocal part (soprano solo or tutti) and the basso continuo. However, the real performances of Franciscan music of that time probably employed a somewhat broader vocal ensemble than these scores may suggest (e.g., markings like "Solo Alto" and "Tenor Solo" in the vocal part of Ms. mus. 245 clearly support such a conjecture), as well as an instrumental accompaniment of strings colla parte and wind instruments ad libitum.

The compositions that stylistically belong to the music of the late seventeenth century (the "first period") can be found among this repertoire in Novo mesto only in Ms. mus. 93. However, there are also many compositions in this book that reflect musical styles of both later periods of development of Franciscan music after the beginning of the eighteenth century. Considering also the great homogeneity of handwriting in this manuscript, it is therefore very likely that Ms. mus. 93 represents a collection of music copied by only one scribe, but from various musical sources of different ages and perhaps also at different periods of time. Moreover, the watermark in the binding of this book suggests that it could not have been produced before 1771 . 